Genome Research 26: 263-270 (2016)

\title{
Corrigendum: Building a genomic framework for prospective MRSA surveillance in the United Kingdom and the Republic of Ireland
}

Sandra Reuter, M. Estée Török, Matthew T.G. Holden, Rosy Reynolds, Kathy E. Raven, Beth Blane, Tjibbe Donker, Stephen D. Bentley, David M. Aanensen, Hajo Grundmann, Edward J. Feil, Brian G. Spratt, Julian Parkhill, and Sharon J. Peacock

The authors would like to correct the omission of a reference in the first introductory paragraph of the initial publication of this article. The reference has been included in the following sentence:

However, for both lineages, the acquisition of the SCCmec element conferring methicillin resistance and the presence of mutations in gyrA and grlA conferring fluoroquinolone resistance are considered to be major contributors to the success of these epidemic lineages (Horváth et al. 2012; Knight et al. 2012; McAdam et al. 2012; Holden et al. 2013).

The previously omitted reference is:

Horváth A, Dobay O, Kardos S, Ghidán Á, Tóth Á, Pászti J, Ungvári E, Horváth P, Nagy K, Zissman S, et al. 2012. Varying fitness cost associated with resistance to fluoroquinolones governs clonal dynamic of methicillin-resistant Staphylococcus aureus. Eur J Clin Microbiol Infect Dis 31: 2029-2036.

The authors apologize for this omission, which has been corrected online.

doi: $10.1101 /$ gr.228155.117 


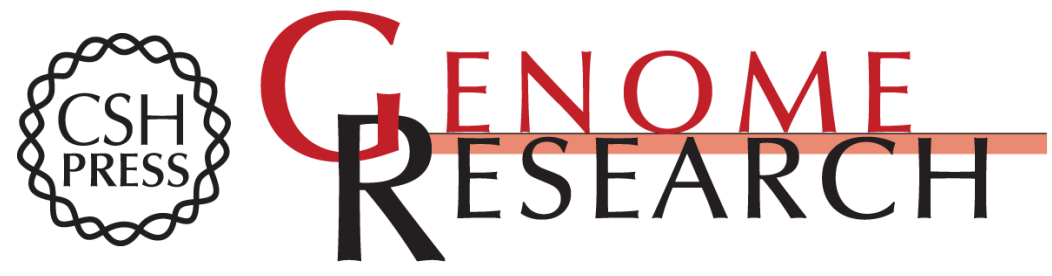

\section{Corrigendum: Building a genomic framework for prospective MRSA surveillance in the United Kingdom and the Republic of Ireland}

Sandra Reuter, M. Estée Török, Matthew T.G. Holden, et al.

Genome Res. 2017 27: 1622

Access the most recent version at doi:10.1101/gr.228155.117

Related Content Building a genomic framework for prospective MRSA surveillance in the United Kingdom and the Republic of Ireland

Sandra Reuter, M. Estée Török, Matthew T.G. Holden, et al.

Genome Res. February , 2016 26: 263-270

Open Access Freely available online through the Genome Research Open Access option.

License

Email Alerting Receive free email alerts when new articles cite this article - sign up in the box at the Service top right corner of the article or click here.

\section{Affordable, Accurate} Sequencing.

To subscribe to Genome Research go to:

https://genome.cshlp.org/subscriptions 